\title{
The Analysis of Environment \\ for the Regional Human Capital \\ Development through the Example \\ of the Krasnoyarsk Territory
}

\author{
Tatiana S. Zimnyakova* \\ Siberian Federal University \\ 79 Svobodny, Krasnoyarsk, 660041, Russia
}

Received 27.10.2016, received in revised form 01.11.2016, accepted 07.11.2016

\begin{abstract}
The human capital is a crucial factor for the innovation economic development. In this sense, the analysis of environment which contributes to its efficient construction becomes especially relevant. This research contains an observation of the financial conditions for the human capital development within a region through the example of the Krasnoyarsk Territory. In the article we analyze the financial situation of the regional economic operators, i.e. households, enterprises, credit institutions and public finances as well. Such investigation has identified worsening of financial conditions for the human capital development. Decreasing purchasing power of the population, concentration of the tax funding and financial flows into the capital region are regarded as negative financial stimuli for the human capital development in the given territory. The results may also be considered as a ground for the corresponding policy implementation within the growing innovation development.
\end{abstract}

Keywords: human capital, innovation development, household finances, regional budget, public finances.

The article is written with the financial support ofthe Regional State Autonomous Institution "Krasnoyarsk Regional Foundation of Scientific and Technical Activities Support", the project "Methodological approaches to the assessment and development of the structural policy of human capital to ensure the sustainable development strategy of the Krasnoyarsk Region territories in terms of diversification and technological modernization of the economy" within the framework of social and human research, development and innovation aimed at improving the quality of life of the Krasnoyarsk Region population in 2016.

DOI: 10.17516/1997-1370-2016-9-11-2765-2784.

Research area: economics, culture studies.

The focus of the world's leading economies on an innovation way of development determines a concern for the human capital as a leading factor of the knowledge-driven economy formation.
The term "human capital" firstly appeared in the second half of $20^{\text {th }}$ century and was linked to Th. Schultz [Schultz, 1981] who investigated the "quality of population" and its influence on

(C) Siberian Federal University. All rights reserved

* Corresponding author E-mail address: tzimnyakova@inbox.ru 
macro - and microeconomic indicators within a territory. More narrowly, at enterprise and personal levels, the human capital was analyzed in the works by G.S. Becker [Becker, 1962]. The evolution of human capital theory was also enriched by S. Kuznets, E. Denison, R. Solow, P.M. Romer, R. Lucas and etc. In the national science this topic was investigated by S.A. Diatlov, M.M. Kritskii, R.M. Nureev and etc. The human capital has been examined through changing angles: as knowledge assets, as a stream of perspective incomes, efficient factor or as workforce function.

At the present time the human capital means a specific type of capital which is, on the one hand, an inseparable part of a human person, and, on the other, - which causes an expansion of intellectual, proprietary or social property assets belonging to persons as well as to enterprises or states [Digilina, 2003]. In other words, the human capital represents a particular productive factor able to a self-increase (capitalization) within the material, spiritual, and social spheres. The self-increase or the human capital development requires special investments, i.e. a commitment in improving the living standards or development of intellectual activity (through the system of education, science and culture). Such investments can, in turn, be sourced from the key economic operators, i.e. households, states and private sector enterprises.
To estimate a financial basis of the regional human capital development, we would like to analyze a financial situation in the state and nonstate economic sectors through the example of the Krasnoyarsk Territory.

\section{Household finances}

The human capital development starts from a family or, to put it in "economic terms", from a household ${ }^{1}$ - an economic unit which includes the consumption of goods/services and human reproduction. The finance situation in this economic unit initially determines the human capital formation and, thus, must be examined more thoroughly.

The household's budget is based on a benefit ratio. In 2015, the total amount of residential income on the Krasnoyarsk Territory was 922467 million rubles, while their cash costs were 912043 million rubles. Taking into consideration the fact that the Territory contains 1097 registered households it would be easy to calculate the average cash budget for one household per month.

In 2015, the budget of an average regional household was formed through the cash income of 70075 rubles per month and cash expenditures of 69283 per month (see Table 1.1).

The first crisis year - 2014 - showed an increase in the population expenditures over

Table 1.1. Key indicators of the household finances on the Krasnoyarsk Territory in 2015 [The Krasnoyarsk Territorial State Statistic Service], [The Federal State Statistics Service]

\begin{tabular}{|l|c|}
\hline \multicolumn{1}{|c|}{ Indicator } & Value \\
\hline Number of households, ths. households & 1097 \\
\hline Average size of households, persons & 2,7 \\
\hline Population income, mln. rubles per year & 922467 \\
\hline Population expenditures, mln. rubles per year & 912043 \\
\hline Average households income, rub per year & 70075 \\
\hline Average households expenditures, rub per year & 69283 \\
\hline
\end{tabular}


their incomes: the residents had to finance their expenditures from the previous savings.

In 2015 the Krasnoyarsk Territory's population incomes exceeded over their expenditures due to the sharp income growth: in 2015 the incomes grew up by $10,66 \%$, while the expenditures - by $5,33 \%$ in comparison with 2014 (Fig. 1.1).

In spite of a strong growth in the incomes in 2015, a real wealth of the Territory's population fell down: a high inflation "absorbed" the biggest part of this growth. It is also evident from the dynamics of real disposable population incomes (Fig. 1.2). The disposable population incomes are a part of incomes which remains available for the households after obligatory payments and fees. Such incomes become "real" after their adjustment for the inflation factor. In 2015 the rate of real disposable population incomes was $97,6 \%$ of the same indicator in 2014 . This means that the disposable population incomes

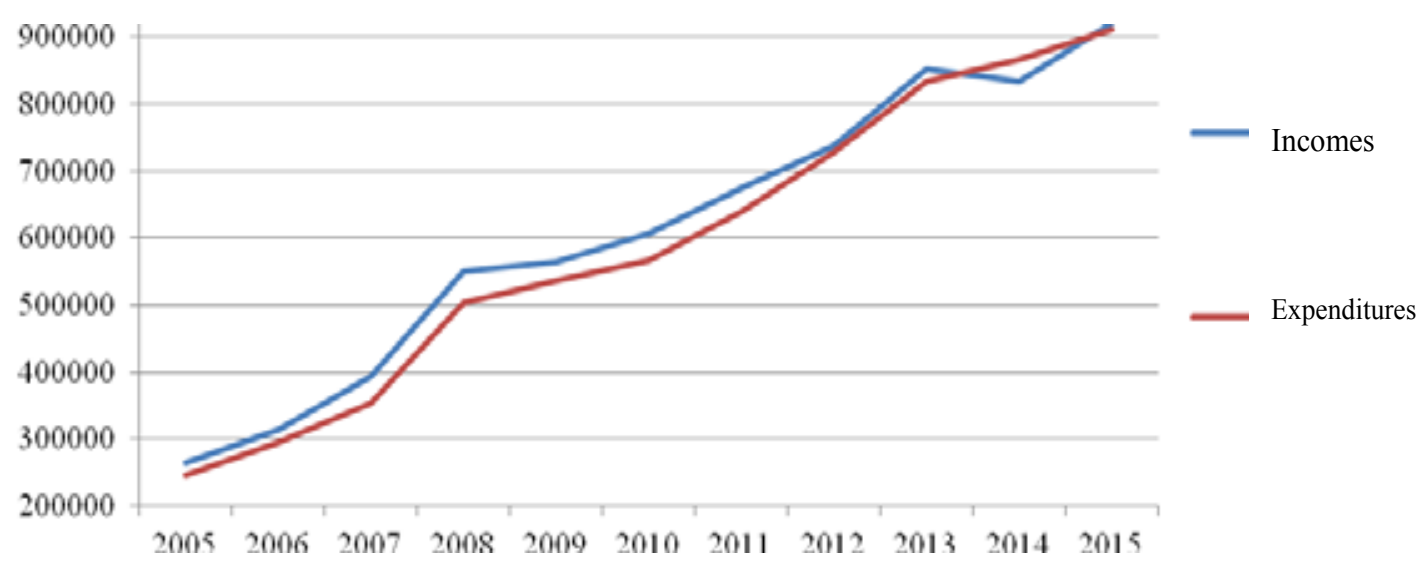

Fig. 1.1. Population incomes and expenditures dynamics in the Krasnoyarsk Territory, mln rub [The Krasnoyarsk Territorial State Statistic Service]

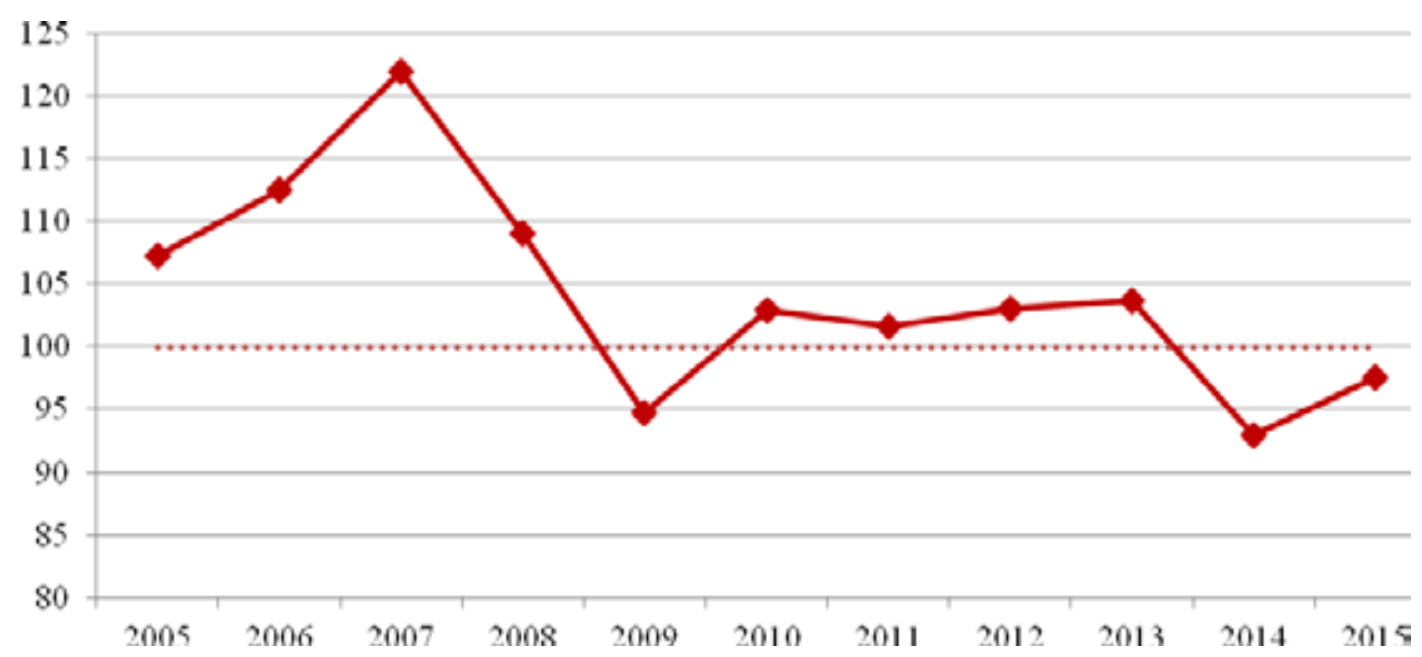

Fig. 1.2. Real disposable population incomes behavior on the Krasnoyarsk Territory, \% to the preceding year 
adjusted for the inflation factor declined by 2,4\% in comparison with 2014.

In 2015, the real disposable population incomes continued their tumbling started in 2014 (Fig. 1.2).

The decline of real incomes leads to an increase in the number of people whose profits cannot ensure even the subsistence minimum.

In 2015, 550000 people in this region got incomes below the living wage. In terms of this indicator the Territory streamed back to the level of 2016 (Fig. 1.3).

General losses in the households' welfare influence their ability to meet the credits. People do not take new loans keeping on canceling the valid ones. As the result, the loan indebtedness per one household had been reducing for two consequent years and in 2015 reached the point of 246590 rub per one household (Fig. 1.4).

Regardless the continuing decline of consumer loan balances, the share of past due debts in the Territory had grown since 2012 and in 2015 has reached 9\% (Fig. 1.4).

Therefore, the main tendency characterizing the situation in household finances of the Krasnoyarsk Territory in 2015 means the erosion of purchasing power. The real population income decreasing has a number of negative consequences. It not only leads to the social unrest intensification by increasing the number of financially disadvantaged citizens, but also bears a risk of credit non-payment, reduction of the demand on goods and services and etc.

If we turn from the general indicators for the household budget to a more detailed analysis of the household incomes structure, then we may trace a tone towards declining share of incomes coming from enterprises activities (the incomes from properties and entrepreneurship) with the increasing role of salaries and social payments in parallel (Fig.1.5).

The entrepreneur activity is regarded as one of the drivers for the human capital development and declining share of incomes from business together with the growth of social benefit shares demonstrates a biar in households' interests from those performed at their peril activity in favor of a sustainable work and state support.

Let's consider the structure of expenditures. The share of consumer expenditures within the total amount of expenditures is increasing each year against the backdrop of decreasing proportion of means aimed at acquiring financial assets (Fig. 1.6).

The households refuse from investments which can generate future incomes in favor of the current consumption of goods and services.

The increasing share of consumer expenditures does not imply the fact that the residents prefer living for now without carrying

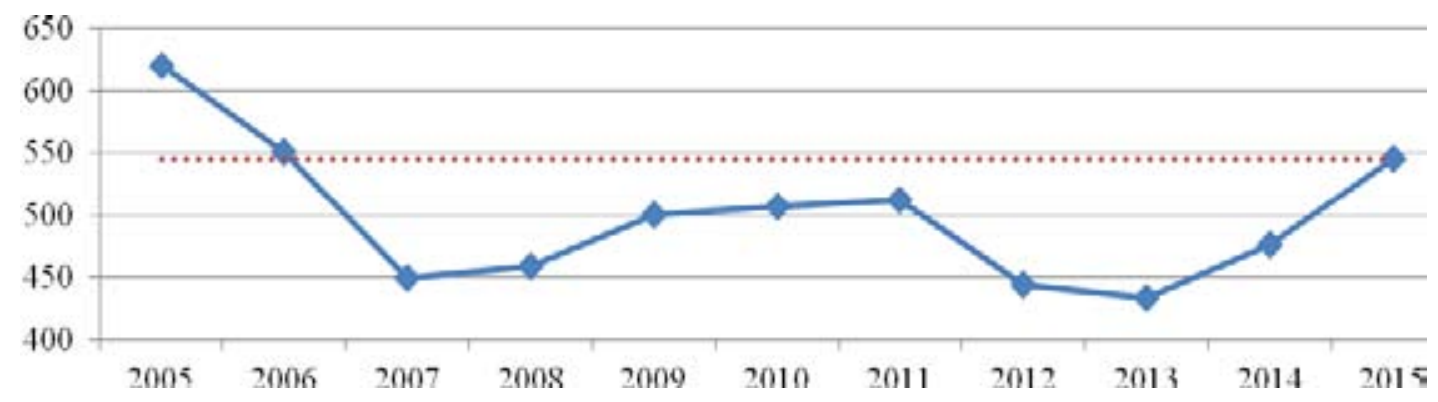

Fig. 1.3. Number of population in the Krasnoyarsk Territory with the incomes below the living wage, ths people [The Krasnoyarsk Territorial State Statistic Service] 


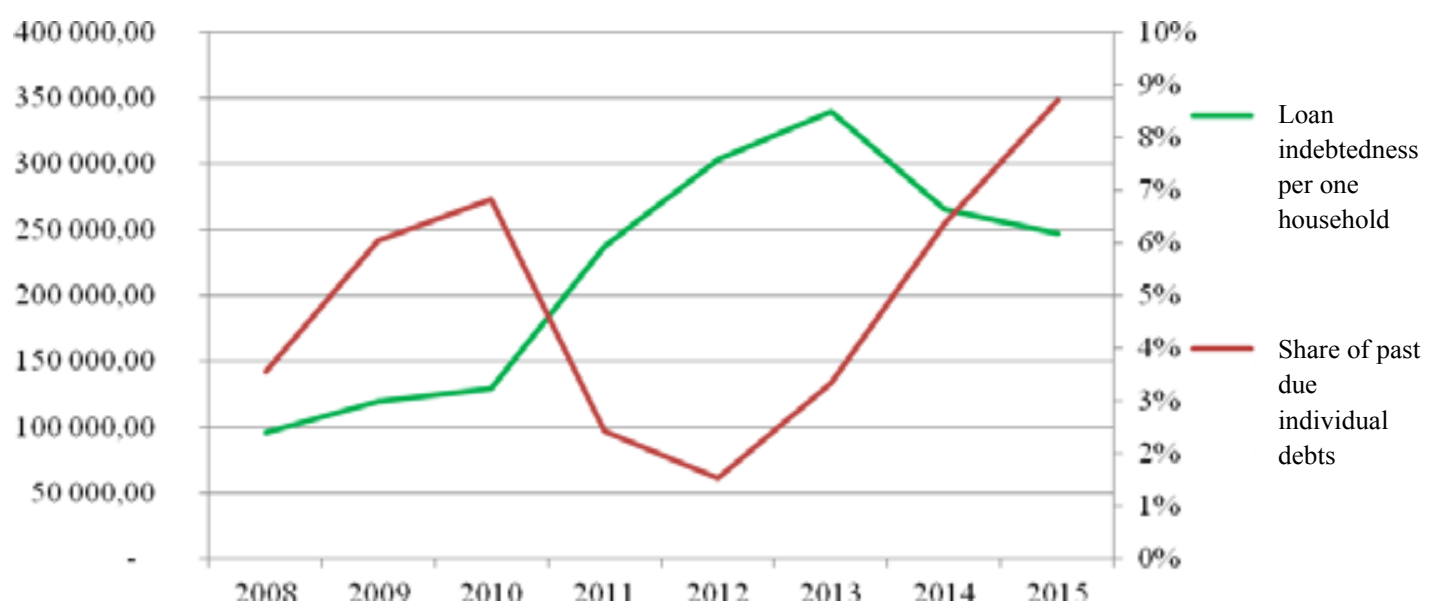

Fig. 1.4. Loan indebtedness per one household (rub.) and the share of past due individual debts in the Krasnoyarsk Territory (\%) [The Bank of Russia]

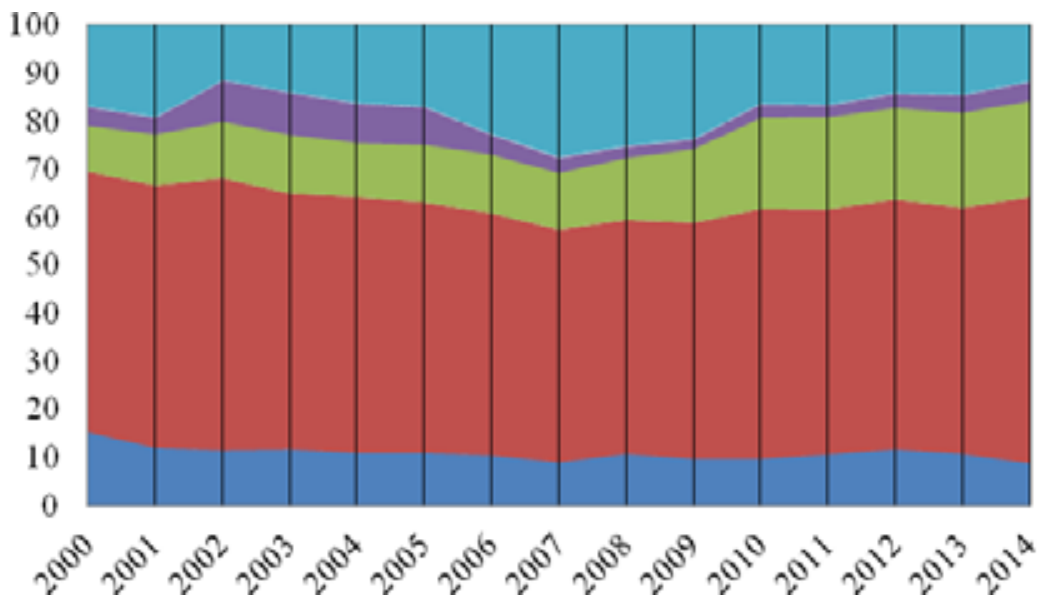

- Other incomes

Property incomes

Social payments

Salaries

Entrepreneurship incomes

Fig. 1.5. Structure of the population incomes in the Krasnoyarsk Territory, \% [The Krasnoyarsk Territorial State Statistic Service]

about their future. The structure of consumer expenditures includes the positions relating to the human capital investing, i.e. spending on education, healthcare and culture.

To estimate the amount of investments contributed in the human capital by the population, we can compare them with the similar household expenditures in the USA (Table 1.2).

The analysis has brought the expected result: in the Krasnoyarsk Territory, the private household expenditures spent on education and healthcare are significantly lower as opposed to the American ones both in absolute numbers and in per cents to the total amount of consumer expenditures.

It is interesting to note that as compared to the USA under much less share of expenditures related to the human capital investing, the share of expenditures on housing and public facilities is considerably higher: 9,2\% in the Territory as against 7,2\% in the USA (Table 1.2).

It is worth noting that many of education and healthcare services in this country are funded under the budget and state extra-budgetary funds. 


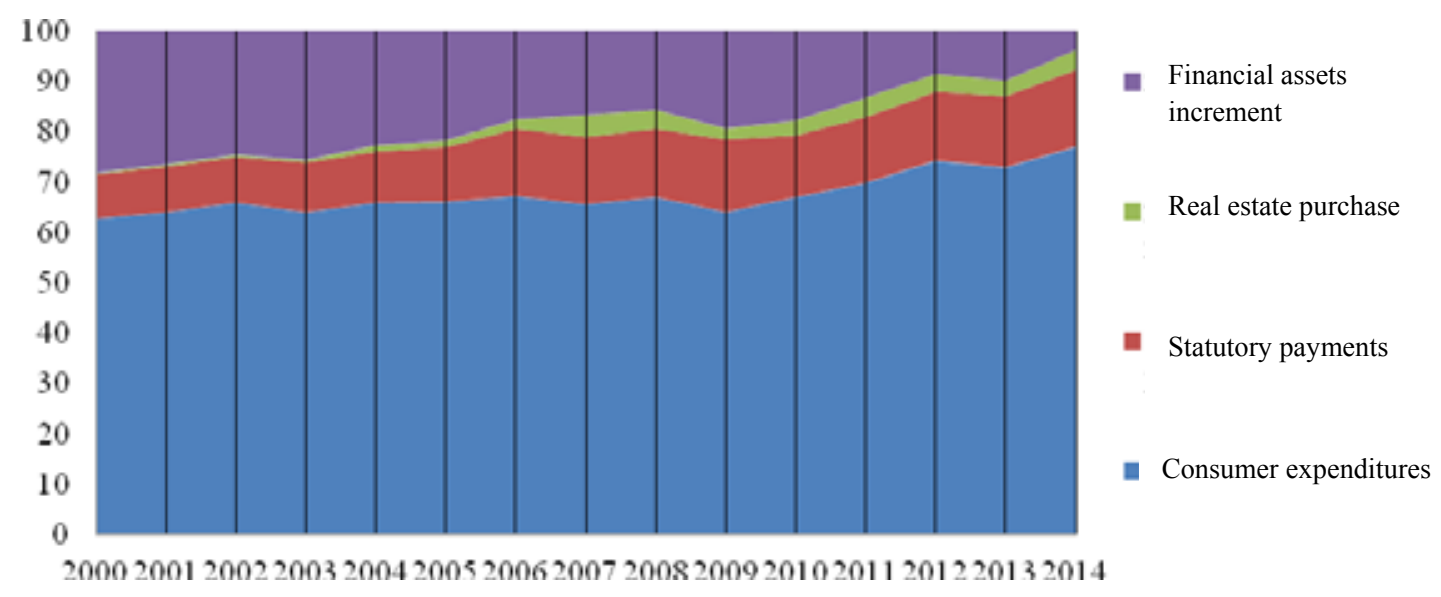

Fig. 1.6 Structure of the population expenditures in the Krasnoyarsk Territory, \% [The Krasnoyarsk Territorial State Statistic Service]

Table 1.2. Comparison of monthly consumer expenditures for the average household in the Krasnoyarsk Territory and in the USA (Calculated from [The Krasnoyarsk Territorial State Statistic Service] and [U.S. Bureau of Labor Statistics] data)

\begin{tabular}{|l|c|c|c|c|}
\hline \multirow{2}{*}{} & \multicolumn{2}{|c|}{$\begin{array}{c}\text { Households in the Krasnoyarsk } \\
\text { Territory, 2015 }\end{array}$} & \multicolumn{2}{c|}{ Households in the USA, 2015 } \\
\cline { 2 - 5 } & $\begin{array}{c}\text { Total amount, } \\
\text { rub }\end{array}$ & $\begin{array}{c}\text { Share in con- } \\
\text { sumer expendi- } \\
\text { tures, \% }\end{array}$ & $\begin{array}{c}\text { Total amount, } \\
\text { rub. }\end{array}$ & $\begin{array}{c}\text { Share in con- } \\
\text { sumer expendi- } \\
\text { tures, \% }\end{array}$ \\
\hline Consumer expenditures including: & $\mathbf{4 8 ~ 1 2 0}$ & 100,0 & $\mathbf{1 6 4} \mathbf{4 0 1}$ & 100,0 \\
\hline products and goods & $\mathbf{3 4 ~ 1 3 1}$ & 70,9 & & \\
\hline service expenditures including: & $\mathbf{1 3 9 8 9}$ & 29,1 & & \\
\hline - housing and public facilities & 4401 & 9,2 & 12007 & 7,3 \\
\hline - education & 705 & 1,5 & 3668 & 2,2 \\
\hline - healthcare & 488 & 1,0 & 11622 & 7,1 \\
\hline - culture (entertainment) & 172 & 0,4 & 7992 & 4,9 \\
\hline
\end{tabular}

Thus, to obtain a complete picture of education and healthcare funding per one household we shall weigh not only the household expenditures per se, but also the public ones provided for these targets.

Since the sphere of education and healthcare are funded not only from the regional budget, it is quite reasonable to ground our calculations on the figures of consolidated budget of the Russian Federation.

These calculations show that the expenditures spent on education services provided to one household in the Krasnoyarsk Territory are paid by this household itself in the amount of 705 rubles and also by the state in size of 4803 rubles per month (Table 1.3) what is totally estimated as 5508 rubles per month. In the USA this figure -7605 rubles per year - does not so much exceed the amount of expenditures in Russia. The healthcare in the USA is recognized as the most expensive one within the whole world, that is why, despite of a significantly less governmental support (2 005 rub per year for one household), the total 
Table 1.3. Expenditures related to the investment in human capital in the Krasnoyarsk Territory and the USA in terms of one household, rub per year [The Krasnoyarsk Territorial State Statistic Service], [Atlas New America]

\begin{tabular}{|l|c|c|}
\hline & Krasnoyarsk Territory & USA $^{3}$ \\
\hline Education: & $\mathbf{5 5 0 8}$ & $\mathbf{7 6 0 5}$ \\
\hline - household expenditures & 705 & 3662 \\
\hline - public expenditures & $4803^{4}$ & $3943^{5}$ \\
\hline Healthcare: & $\mathbf{7 4 7 1}$ & $\mathbf{7 6 8 0 9}$ \\
\hline - household expenditures & 488 & 11625 \\
\hline - public expenditures & $4005^{6}$ & $2005^{7}$ \\
\hline - fund expenditures and etc. & $2978^{8}$ & $63179^{9}$ \\
\hline
\end{tabular}

sum of expenditures on the healthcare services in that country is well above the Russian one (Table 1.3).

Obviously, the funding gap in the Russian healthcare dramatically reduces its quality: they cannot afford sophisticated equipment and low salaries for doctors do not encourage them to perform at a high level.

Thus, the analysis of the situation in household finances within the Krasnoyarsk Territory has indicated a number of crucial trends:

- Purchasing power of the Territory's population is decreasing;

- Share of incomes from the entrepreneur activity is reducing;

- Total household and public expenditures on education are relatively high, yet much of them are spent by the state;

- Total household and public expenditures on healthcare are relatively low that negatively influences on the quality of healthcare services;

The trends mentioned above reflect those financial drivers that move the human capital throughout the Territory: being financially supported by the state, the education attracts young people to study within their native territory and then migrate to those places where their business talent and skills will be demanded and ensure them with better healthcare or other living conditions.

\section{Public finances}

A potential for the human capital development is definitely linked with the conditions set for a comfortable life and activity of the population in the given territory. Back to 1841, Friedrich List, a German economist, pointed out that "the arts and crafts travel from one city to another or from one country to another. Being tracked or dejected in their native territory, they find an asylum in those cities and countries which can provide them with freedom, protection and support [List, 2005]". Since so, a significant role in the creation of suitable environment is played by the state which set legal, economic and social frameworks for the human capital existence.

At the level of federal subjects one of the ways to create such terms means redistribution of financial flows through the budget system. The financing priorities determined within the federal entity's budget represent a set of options for the territory development and form certain environment where the human capital can perform.

To identify the financial conditions for the human capital development in the Krasnoyarsk Territory we have analyzed the character and courses of the public financial flows in this region.

The Territory's public finances are based on the territorial budget. There, in recent years, the excess of expenditures over incomes has 


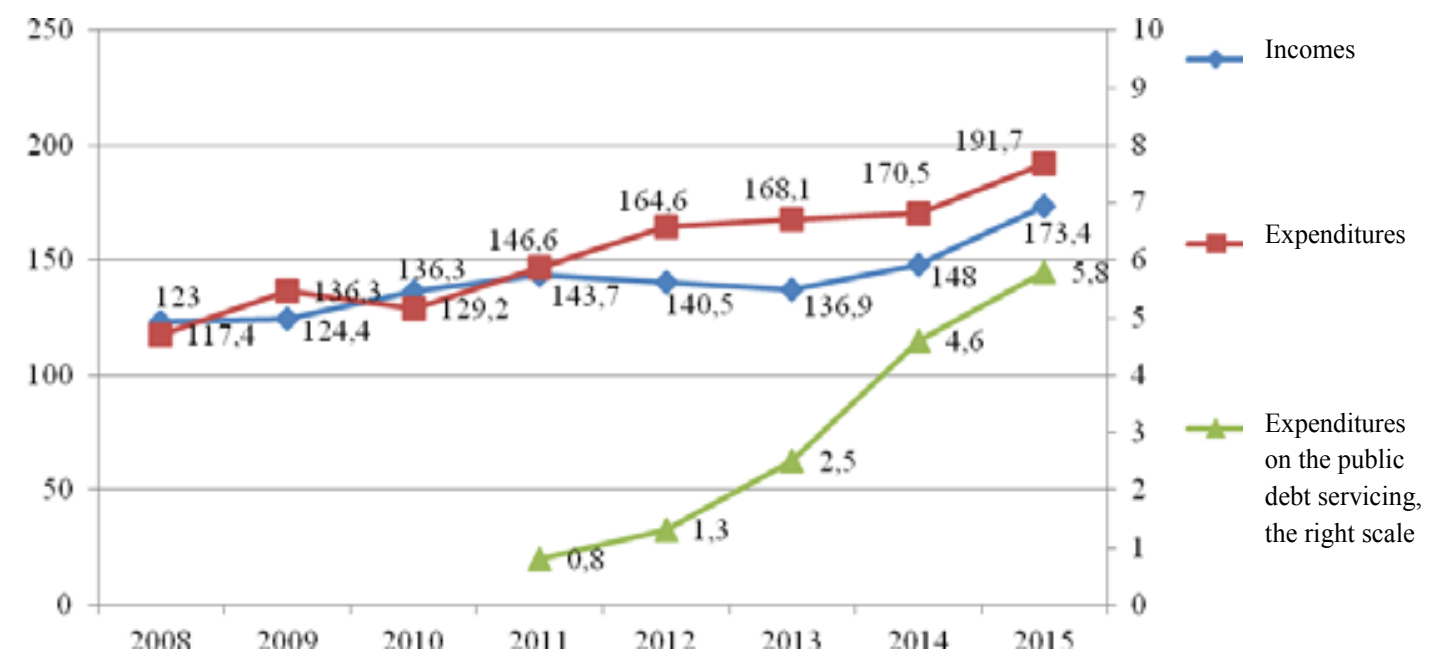

Fig. 2.1. Incomes and expenditures in the budget of the Krasnoyarsk Territory and expenditures on the public debt servicing, bln rub [The Ministry of Finance of the Krasnoyarsk Territory]

been recognized as the main trend (Fig. 2.1). The territorial budget deficit reached its maximum in 2013 (31,2 billion rubles) followed by a fall for two years in a row.

In 2015 the territorial budget deficit was 18,3 billion rubles or $1 \%$ of GRP that means an acceptable indicator ${ }^{10}$.

Within the deficit budget time the Territory has enhanced a public debt which has increased demonstrating an exponential growth dynamics (Fig.2.1). Still, there is no surprise: following the results of 2015 the total sum of public debt in the Krasnoyarsk Territory has reached 84,7 bln rubles rising 73-times over the past 8 years.

Per one territorial resident the public debt in 2015 was 29560 rubles (increased by 23\% comparing with 2014 regardless the Territory's budget deficit cutting in 2014 - 2015 (Fig. 2.2)).

The GRP growth rate per capita is obviously far behind the subfederal debt growth rate given that the GRP growth in $2014-2015$ was mainly influenced by the inflationary tendencies.

Structurally the territorial public debt is dominated by securities (Fig.2.3) that is a positive moment: they are a "cheaper" way to finance the budget deficit comparing with bank credits.
Still, in the recent years there has been a tendency to increase the share of loans in credit institutions with a declining share of budget credits and loans in parallel (Fig.2.3).

In general, despite a worrying growth dynamics of the public debt and expenditures on its servicing, the territorial finance policy can be recognized as a satisfactory one. It creates a general, favorable and sustainable environment for the territorial economy performing.

More profound trends of the finance flows formation in the Krasnoyarsk Territory enable us to analyze the structure of incomes and expenditures of the territorial budget.

The major sources which build the territorial budget income include a company tax, personal income tax and non-repayable receipts (Fig. 2.4). In 2015 the share of company tax in the total amount of the budget income was $34.54 \%$, personal income tax $-23,18 \%$ and non-repayable receipts $-17,36 \%$.

The behavior of territorial budget structure has been clearly demonstrated by a breakdown in the income tax collection in 2009 caused by the crisis of 2008. A share of gaps in the budget income increased in 2009 up to $44 \%$. Since that 


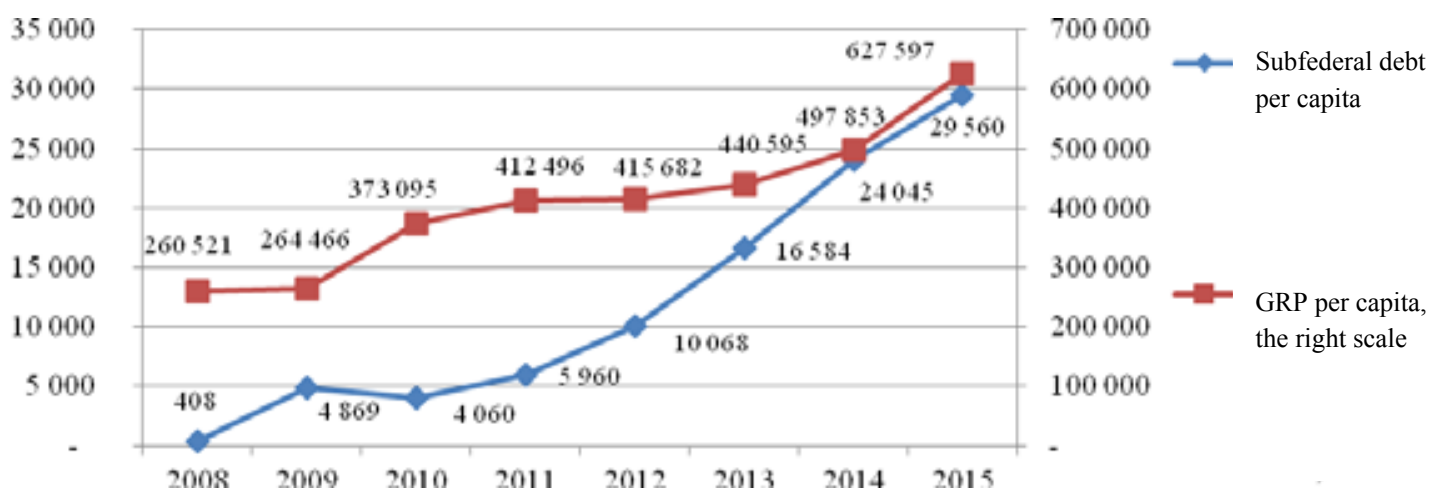

Fig. 2.2. Public debt and GRP of the Krasnoyarsk Territory per capita, rub [The Krasnoyarsk Territorial State Statistic Service], [The Ministry of Finance of the Krasnoyarsk Territory]

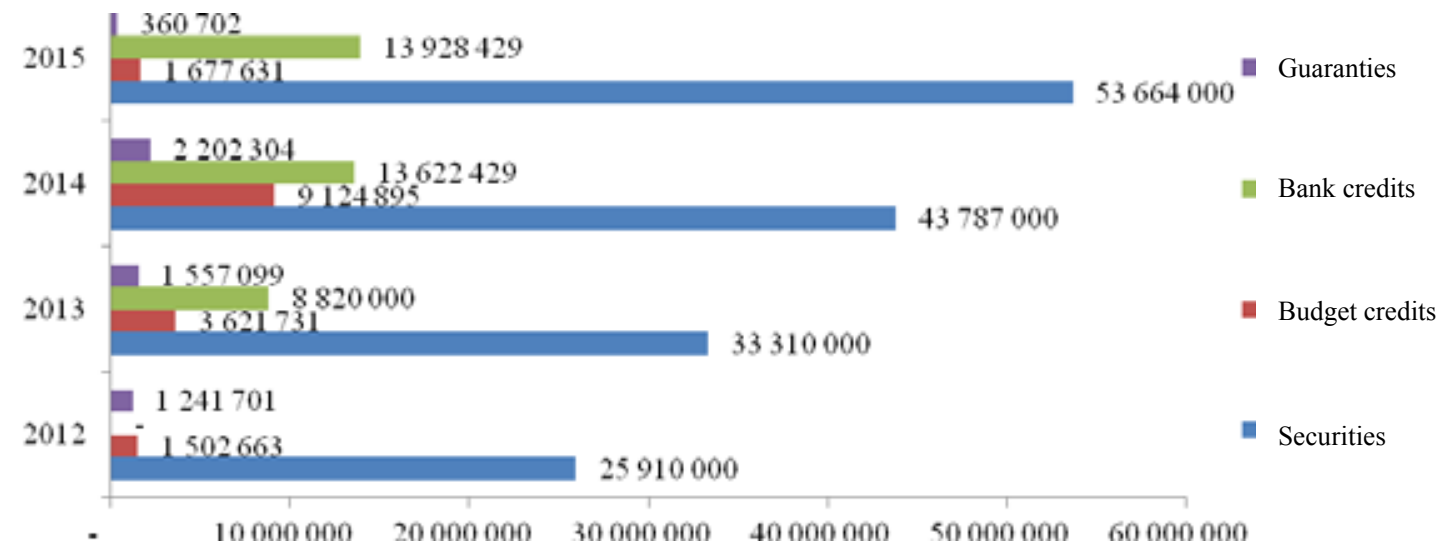

Fig. 2.3. Structure of the public debt of the Krasnoyarsk Territory, ths rub [The Ministry of Finance of the Krasnoyarsk Territory]

time, the territorial income base has strengthened scaling down the share of non-repayable receipts for the regional budget.

This time in the Krasnoyarsk Territory the major role in the income part enrichment is played by a "success tax" for the territorial households, i.e. the company taxes and personal income taxes. Cumulatively, they account for more than a half of the total territorial budget (Fig. 2.4).

In the structure of territorial budget expenditures the attention is drawn by changes occurred in 2010 - 2011: a sharp decline in the proportion of inter-budgetary transfers in municipalities and, simultaneously, an increase of the budget costs on education, healthcare and social policy (Fig. 2.5). This is explained by two reasons: firstly, there has been a transfer of expenditures obligations on the social sphere from the local level to the subfederal one, and, secondly, there has been an active work on the May Decrees implementation. Just in 2015 54,6 bln rub ${ }^{11}$ was spent to enforce these decrees.

The social support for the population of this country and territory is increasing each year. In the terms of annual decrease of the real disposable population incomes (refer to Paragraph 1, Fig. 1.2), an increasing support for 


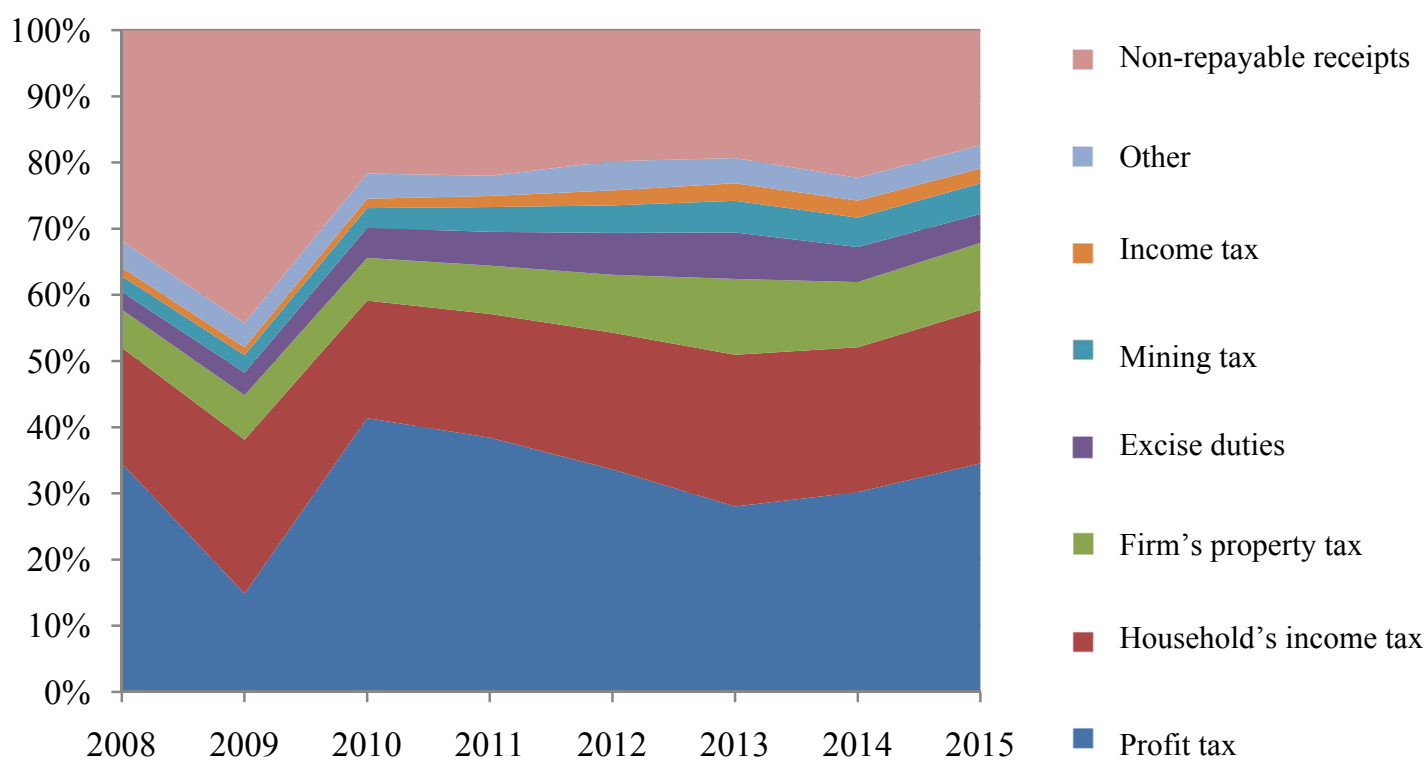

Fig. 2.4. Structure of the territorial budget income, $\%$ to the total sum of incomes [The Ministry of Finance of the Krasnoyarsk Territory]

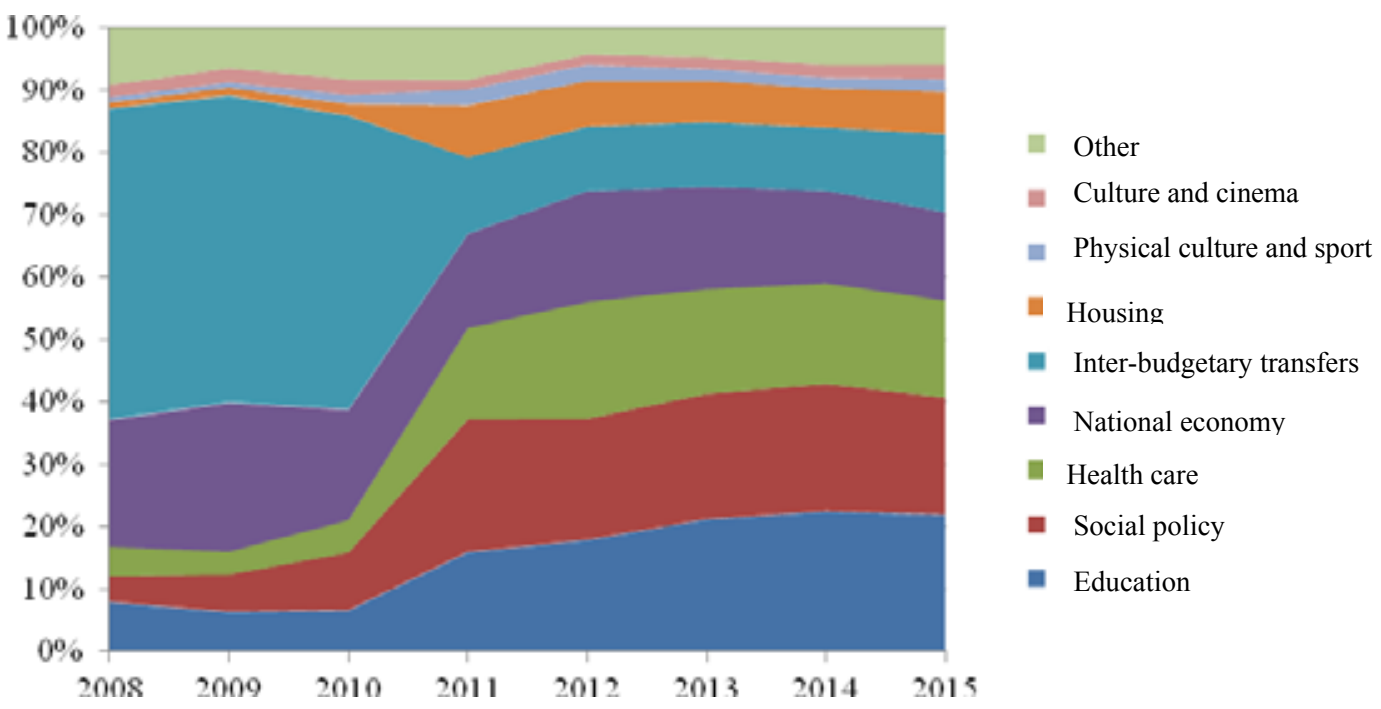

Fig. 2.5. Structure of the territorial budget expenditures, \% to the total sum of expenditures [The Ministry of Finance of the Krasnoyarsk Territory]

the territorial residents has a great importance for the social tensions alleviation. Nevertheless, an excessive social support implies a risk to lose the population's interest in work and development that reduce the potential of human capital.
If we exclude intra-budgetary circulations in the Territory between the federal subject and municipal entities and consider the consolidated budget, then the trends described above will occur more vividly.

The total share of profit tax and personal income tax has dropped from $60 \%$ in 2011 to 


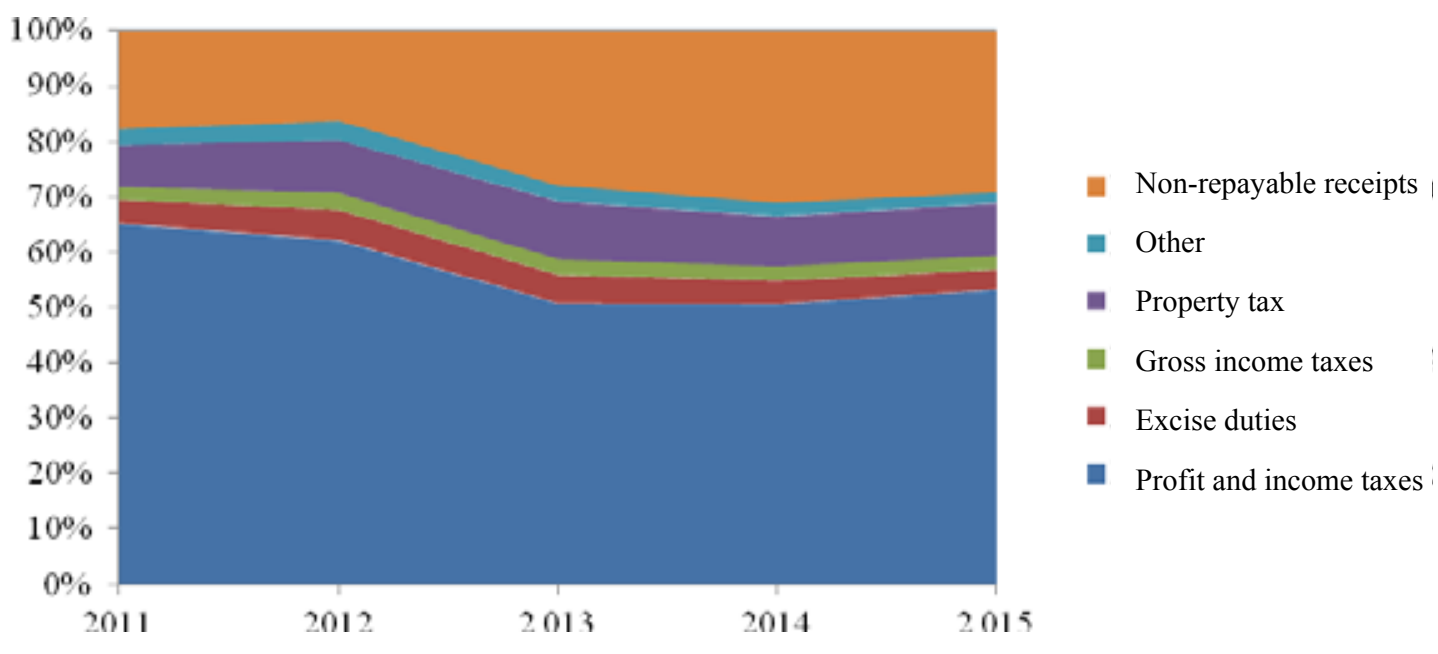

Fig. 2.6. Structure of the consolidated budget incomes in the Krasnoyarsk Territory including the non-budgetary fund, $\%$ to the total sum of incomes [The Ministry of Finance of the Krasnoyarsk Territory]

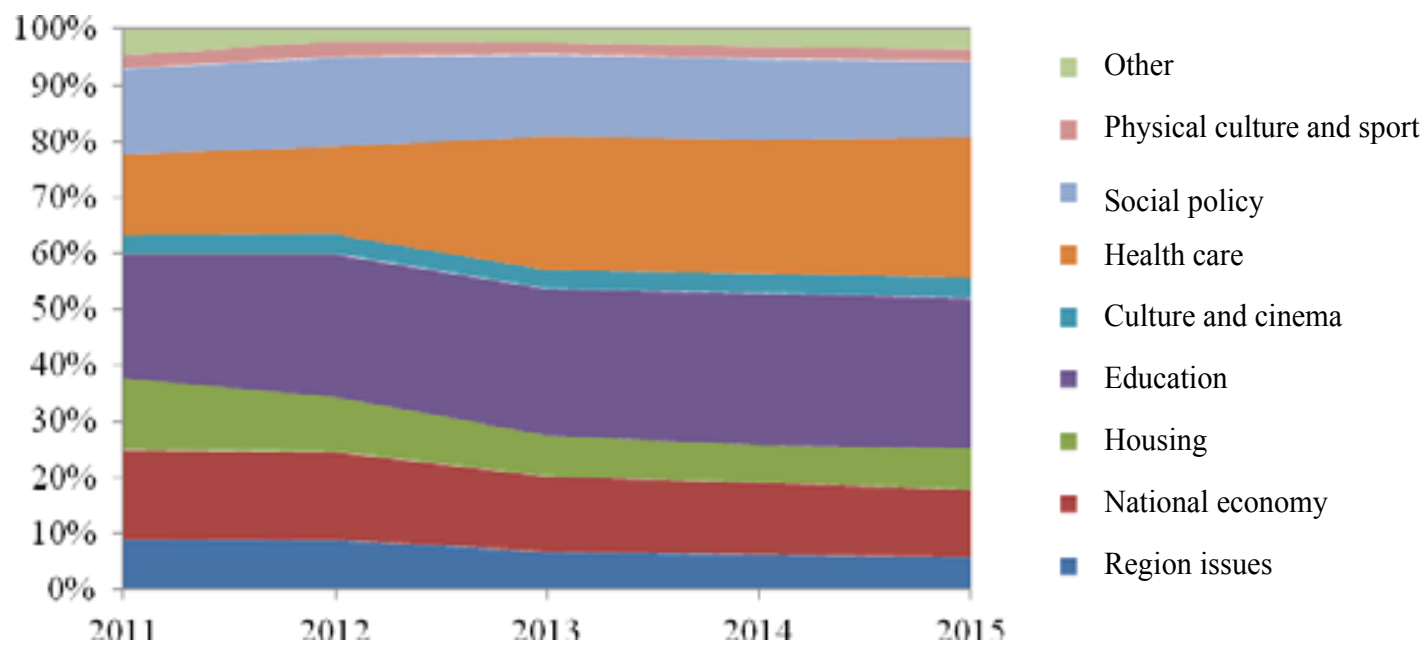

Fig. 2.7. Structure of the consolidated budget expenditures in the Krasnoyarsk Territory including the nonbudgetary fund, \% to the total sum of expenditures [The Ministry of Finance of the Krasnoyarsk Territory]

$50 \%$ in 2015 . At the same time, the share of nonrepayable receipts has risen from $16 \%$ to $27 \%$ relatively (Fig. 2.6)..$^{12}$

The biggest part of costs in the consolidated budget is taken by expenditures on the social sphere: in $201527 \%$ was spent on education, $25 \%$ - on healthcare and $14 \%$ on the social policy (Fig. 2.7).13

The growth of non-repayable receipts share within the combined income of the consolidated budget is not related to the tax collection reducing in the Krasnoyarsk Territory. Indeed, the amount of paid taxes is rapidly increasing (Fig. 2.8). Still, a part of taxes kept within the federal subject's incomes is declining. More and more taxes collected in this territory are contributed into the federal budget intensifying dependence of the territorial finances on Moscow's investments. 


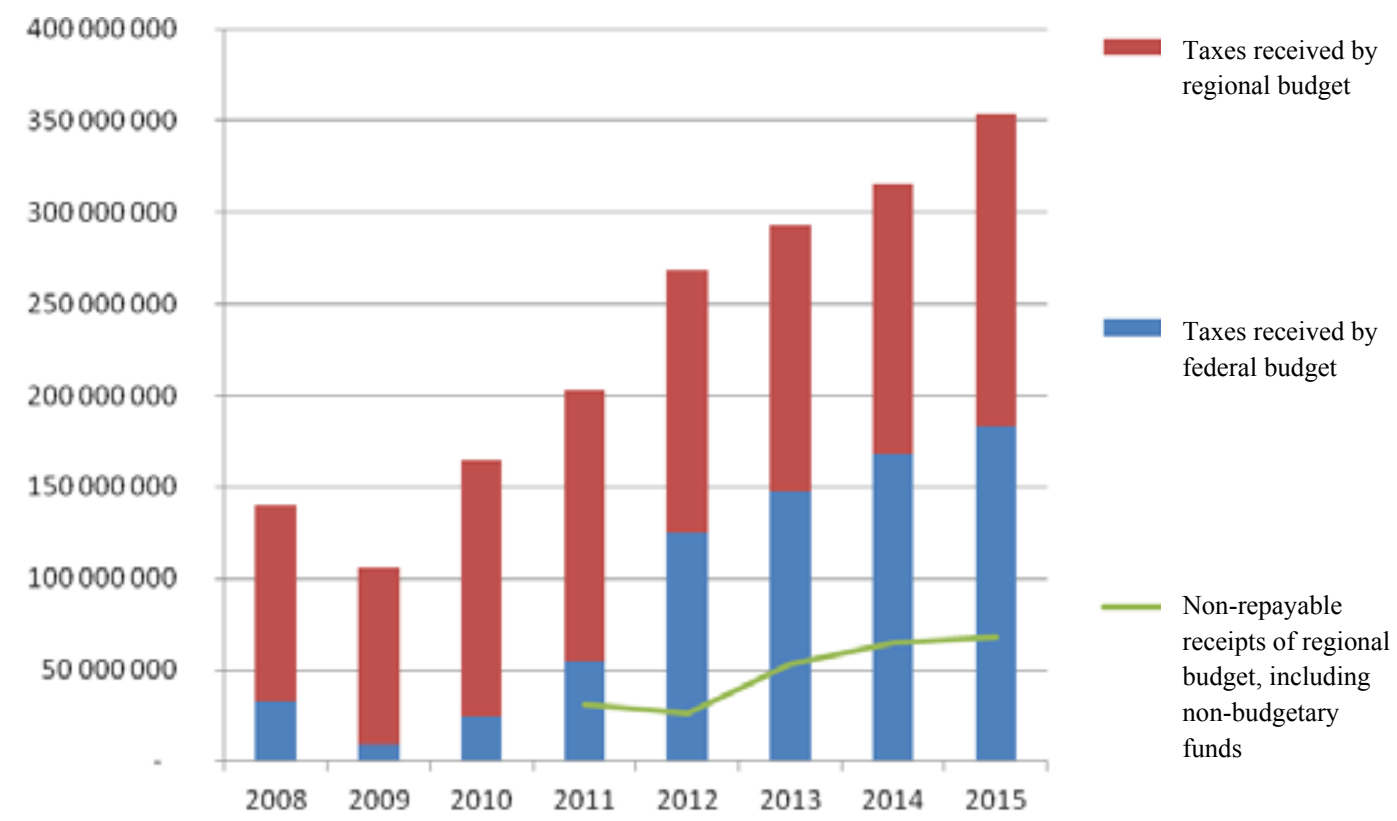

Fig. 2.8 Taxes collected in the Krasnoyarsk Territory and their further distribution between the federal and subfederal budgets, ths rub [The Federal Tax Service], [The Ministry of Finance of the Krasnoyarsk Territory]

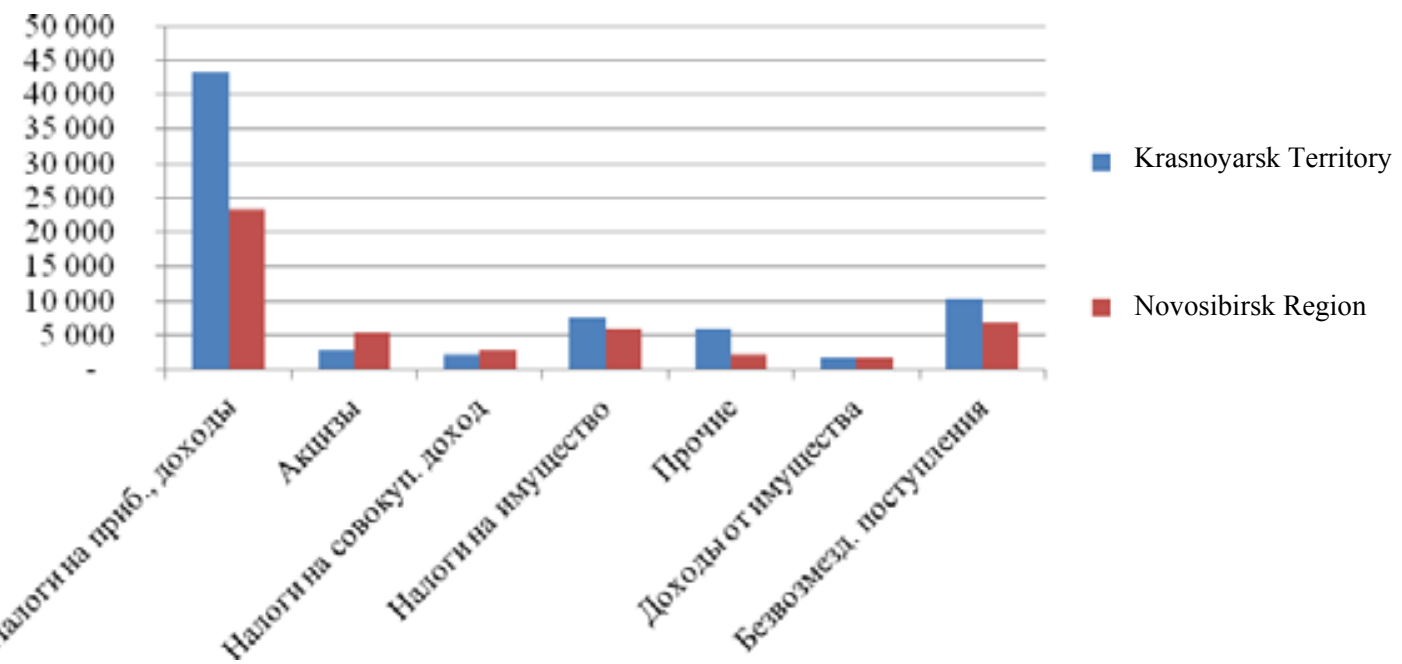

Fig. 2.9 Structure of the consolidated budget incomes in the Krasnoyarsk Territory and the Novosibirsk Region, rub per capita [The Ministry of Finance of the Krasnoyarsk Territory], [State Statistics]

The financial situation in the Krasnoyarsk Territory is also typical for many other subjects of the Russian Federation. The Fig. 2.9 and 2.10 contain a comparison between incomes and expenditures of the Krasnoyarsk Territory and the Novosibirsk Region per capita.
The structure of the budget incomes and expenditures in the given territories is similar even though almost in all the positions, in the Krasnoyarsk Territory one inhabitant accounts for more money than in the Novosibirsk Region. Such situation is mainly conditioned upon the 


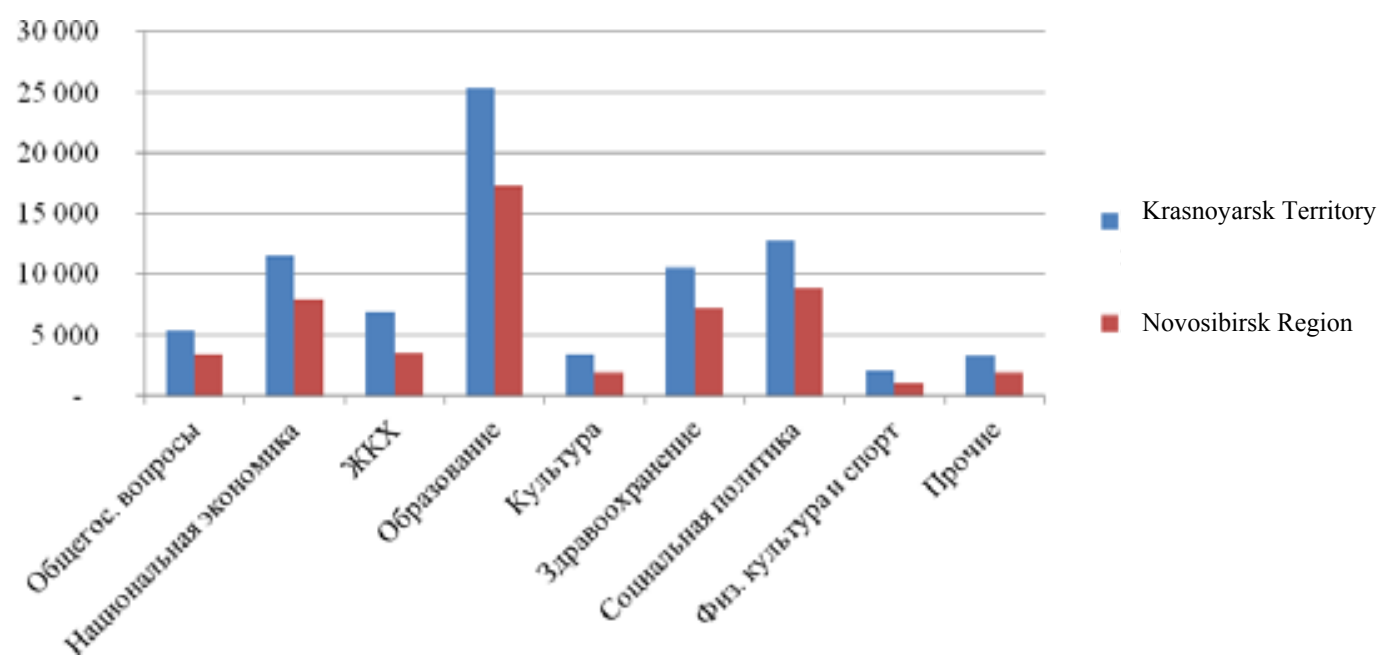

Fig. 2.10 Structure of the consolidated budget expenditures in the Krasnoyarsk Territory and the Novosibirsk Region, rub per capita [The Ministry of Finance of the Krasnoyarsk Territory], [State Statistics]

inclusion of the northern and, consequently, more cost requiring areas into this territory.

Thus, the analysis of the public finances in the Krasnoyarsk Territory allows drawing the following line:

- General status of the territorial finances is balanced; the public debt has been formed mainly by the securities, though the share of bank credits has been increasing.

- Public finance incomes in the Krasnoyarsk Territory are predominantly characterized by "success taxes", i.e. by the profit taxes and personal incomes taxes.

- The expenditure side of the Krasnoyarsk Territory's consolidated budget is inherent to a social focus: the main part of expenditures is spent on education, healthcare and social policy.

- Although there has been noted an increasing amount of taxes collected in the Krasnoyarsk Territory, a significant funding for the expenditures it receives in the form of nonrepayable receipts from the Federation.

The analysis of the public finances sources and priorities in expenditures in the Krasnoyarsk Territory has demonstrated that the public budgetary policy is primarily oriented on the social protection. In the terms of worsening financial situation in the household sector, the primacy of population support reduces social tensions and makes such benefits as general education and healthcare more available. Still, such contributions only partially can be considered as investments in the human capital. Without encouraging business activities of the population, the human capital can hardly take roots in this territory. Globalization of national economies and increasing cosmopoliticity in views make the leakage of human capital into more not only appropriate living environment, but into a productive one, easier.

\section{Corporate finances and banking sector}

The economic activity of enterprises forms a basis of financial flows in the overall economy: payment of taxes, salaries, revenues to owners provides the state and households with incomes. That is why, those tendencies peculiar to the corporate finances directly impact the finances of other economic entities and their abilities to invest in the human capital development. 
Table 3.1. Corporate pre-tax profit in the Krasnoyarsk Territory by economic activities, 2015 [State Statistics]

\begin{tabular}{|l|c|c|}
\hline Sections in the Russian National Classifier of Economic Activities (OKVED) & $\begin{array}{c}\text { Profit as to } \\
\mathbf{0 1 . 0 1 . 2 0 1 6 ,} \\
\text { ths rub }\end{array}$ & Share, \% \\
\hline Total & $\mathbf{3 1 8 ~ 2 7 5 ~ 9 5 6}$ & $100,00 \%$ \\
\hline Section D Manufacturing & 259439169 & $81,51 \%$ \\
\hline Section F construction & 4561492 & $1,43 \%$ \\
\hline $\begin{array}{l}\text { Section G Wholesale and retail trade; vehicles, motorbikes, household products and } \\
\text { personal goods repair }\end{array}$ & 3726335 & $1,17 \%$ \\
\hline Section I Transport and communications & 2560369 & $0,80 \%$ \\
\hline Section J Finance activity & 281877 & $0,09 \%$ \\
\hline Section K Real estate operations, renting and service delivery & -22665357 & $-7,12 \%$ \\
\hline Section L Public administration and military defense; social security & 6055 & $0,00 \%$ \\
\hline Section M Education & -18779 & $-0,01 \%$ \\
\hline Section N Healthcare and social services & 108930 & $0,03 \%$ \\
\hline Section O Provision of other communal, social and personal services & -484339 & $-0,15 \%$ \\
\hline Section A Agriculture, hunting and forestry & 2106008 & $0,66 \%$ \\
\hline Section B Fishery, fish farming & 7506 & $0,00 \%$ \\
\hline Section E Production and distribution of electric power, gas and water & 14375450 & $4,52 \%$ \\
\hline Section H Hotels and restaurants & -74093 & $-0,02 \%$ \\
\hline Section C Mineral production & 54345333 & $17,07 \%$ \\
\hline
\end{tabular}

The "soundness" of corporate finances can be evaluated through a number of indicators the information about which has been accumulated by the state statistics authorities: pre-tax profit (losses), receivables and payables, profitability (unprofitability) of sold goods, products, services and works (Fig. $3.1-5$ ).

$99 \%$ of the corporate pre-tax profit in the Krasnoyarsk Territory are formed by two types of companies: with manufacturing activity (82\%) and mineral production (17\%) (Table 3.1). Working in these sectors, the companies represent leading taxpayers and employers in the Krasnoyarsk Territory.

The behavior of manufactories indicates a non-stable growth over the past 9 years while the profit of producing companies has been declining since 2011 subject to the oil price (Fig. 3.1).

Due to a prevailing role of manufacturing industries in the Krasnoyarsk Territory's economy, the total profit of all the territorial enterprises shows a positive dynamics over the last three years (2013 - 2015), against a downward trend in producing sector within the given period (Fig. 3.2)

The total corporate profit growth rate in this territory does not keep pace with the average national and regional (within Siberian Federal District) dynamics (Fig.3.2). At the same time, the average profitability of products, goods and services in the Krasnoyarsk Territory considerably exceeds this indicator within the RF and Siberian Federal District (Fig.3.3).

While the corporate efficiency exceeds the national level, in the terms of payment records for creditors and debtors the Krasnoyarsk Territory remains far behind. The share of the corporate past-due debts in the total amount of corporate demands has increased from $9 \%$ in 2007 up to $18 \%$ in 2015 , far outnumbering the average level in Russia and Siberian Federal 


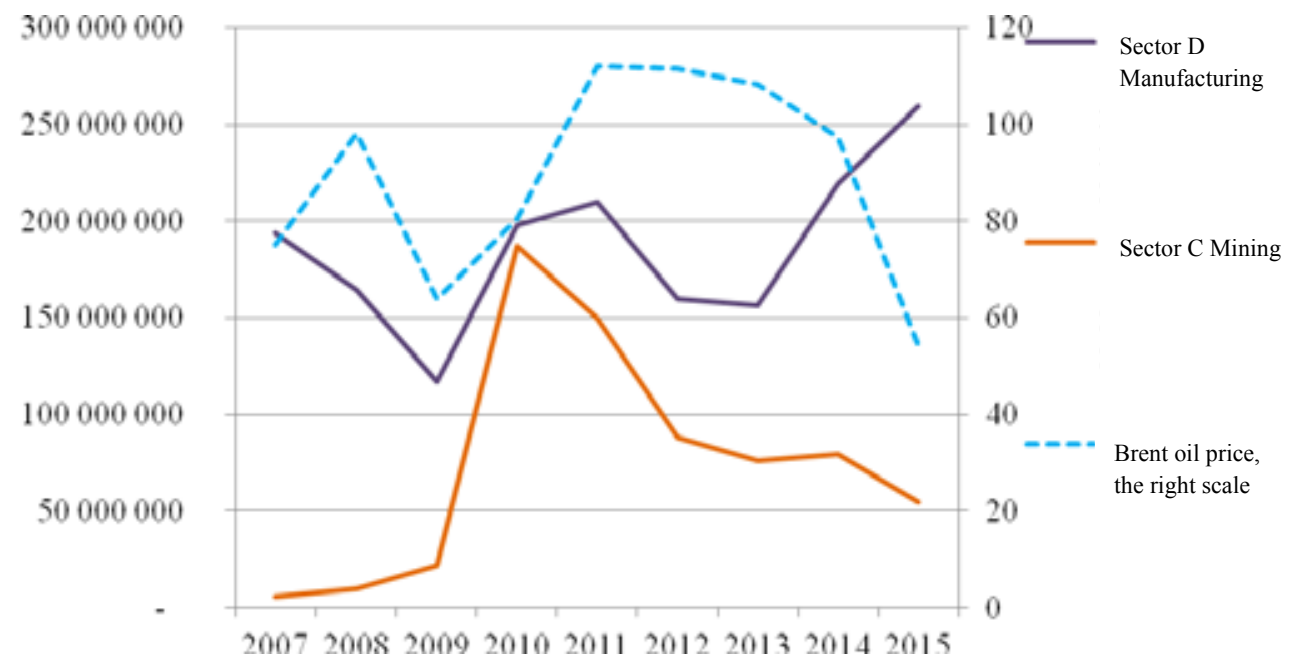

Fig. 3.1. Profit of producing and manufacturing companies in the Krasnoyarsk Territory, ths rub and Dated Brent oil price, US dollars p/b [State Statistics], [Finam - investment company]

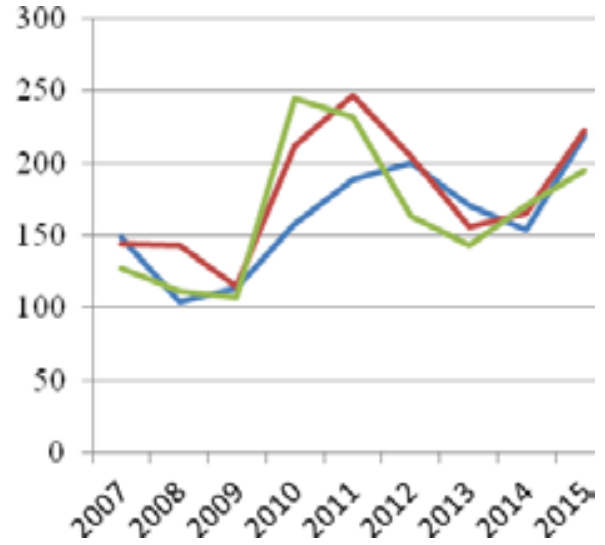

For the blue line - the Russian Federation, for the red line Siberian Federal District, for the green line - the Krasnoyarsk Territory [State Statistics]

Fig. 3.2. Pre-tax profit, growth rate as to $2006, \%$

District (Fig. 3.4). The share of past-due debts in the total amount of credit indebtedness is approximately equal to the national indicator and significantly lower than the one in Siberian Federal District (Fig. 3.5).

Stiffening of the indebtedness demands and obligations points at reducing stability of the territorial corporate finances along with

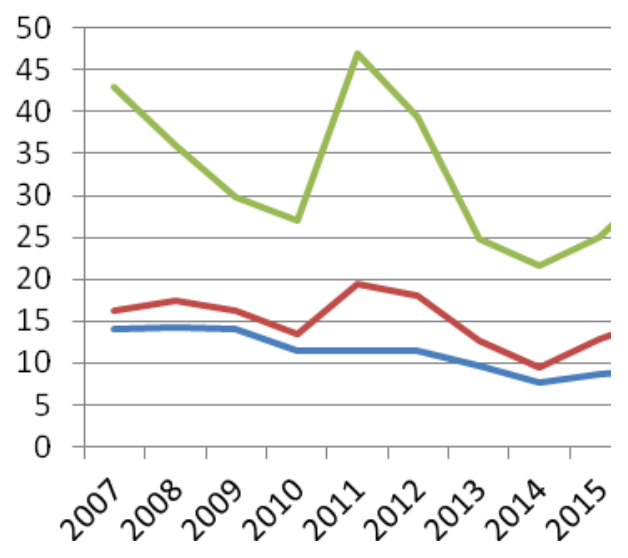

For the blue line - the Russian Federation, for the red line Siberian Federal District, for the green line - the Krasnoyarsk Territory [State Statistics]

Fig. 3.3. Profitability of products, goods, works and services, $\%$

maintaining the position as a region with improved production profitability.

The analysis of corporate finances can be enriched by considering the banking economic sector of the Krasnoyarsk Territory. The credit institutions create an institutional environment for the economic performance and human capital development. By investigating their activity we 


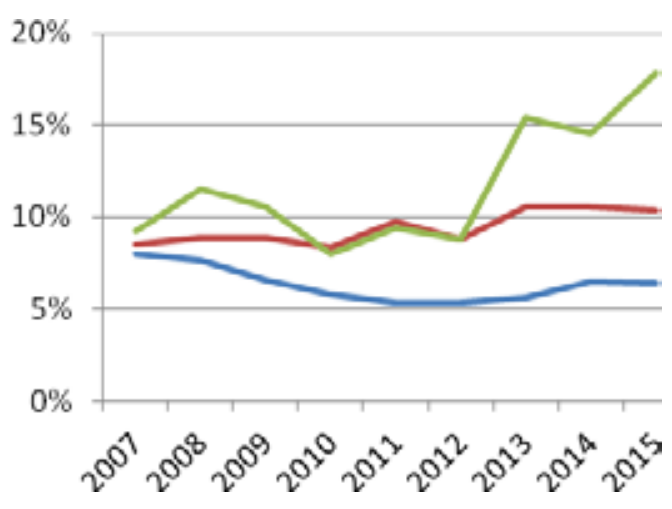

For the blue line - the Russian Federation, for the red line Siberian Federal District, for the green line - the Krasnoyarsk Territory [State Statistics]

Fig. 3.4. Share of past-due debts in the total amount of debtor debts, $\%$

will demonstrate the dominant economic trends through another angle.

The credit institutions performing in the Krasnoyarsk Territory has totally attracted $362002 \mathrm{mln}$ rub as at January 1, 2016 and set for individual and corporate credits $890148 \mathrm{mln}$ rub. The temporary available funds collected in this territory 2,5 times exceed the set ones. It is obvious that in order to lend credits the banks attract funds from other territories and from Moscow as a financial center of this country, in particular. The share of Central Federal District accounts for $66 \%$ of all the obtained banking system means in Russia, among which Moscow is of 55\% [The Bank of Russia].

In the amount of attracted funds the credit institutions hold $18^{\text {th }}$ position in the Russian Federation and $3^{\text {rd }}$ position in Siberian Federal District (following the Novosibirsk and Irkutsk Regions). In the terms of lending it takes $8^{\text {th }}$ place in the RF and $1^{\text {st }}$ place in Siberian Federal District [The Bank of Russia].

As at January 1, 2016 in the Krasnoyarsk Territory physical persons have given $266142 \mathrm{mln}$ rub of deposits to the banking system, and loaned a lower amount - $126264 \mathrm{mln}$ rub, while in the

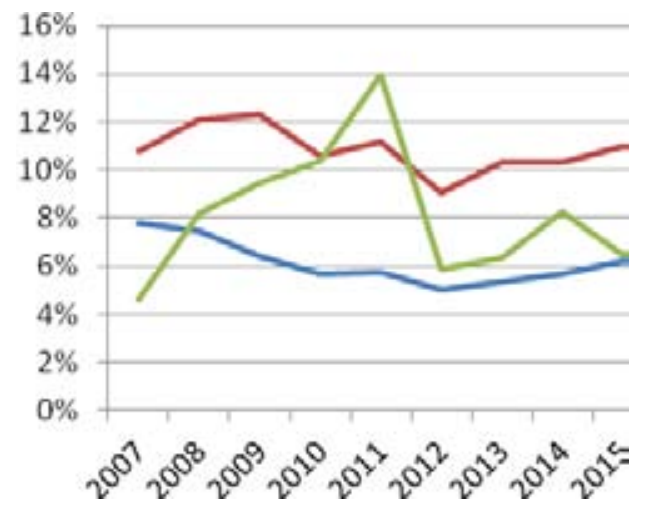

For the blue line - the Russian Federation, for the red line Siberian Federal District, for the green line - the Krasnoyarsk Territory [State Statistics]

Fig. 3.5. Share of past-die debts in the total amount of credit debts, \%

legal persons sector there has been an opposite situation: $95860 \mathrm{mln}$ rub have comprised the obtained corporate funds, and the credits has been accounted for $763884 \mathrm{mln}$ rubles. It implies that the temporary available corporate means are outside the region.

The loans provided to the enterprises in this Territory are of higher quality than in Russia on the average: as at January 1, 2016 the share of past-due indebtedness within the total amount of lending has accounted for $2 \%$ while the average national indicator - for $7 \%$ (Table 3.2)

The situation concerning the past-due indebtedness of households in this region is similar to the average one in Russia: the share of debts in the Krasnoyarsk Territory has been measured for 9\%, in Siberian Federal District $9 \%$ and in Russia $-8 \%$.

The level of banking services development in the Krasnoyarsk Territory can be evaluated through the indicators calculated by the Bank of Russia for all federal entities. The measurement is based on the institution saturation index (И1), finance saturation (И2), thrift industry development index (ИЗ) and cumulative index $(\mathrm{CИ})^{14}$. 
Tatiana S. Zimnyakova. The Analysis of Environment for the Regional Human Capital Development through the Example...

Table 3.2. Share of the past-due indebtedness in the total amount of lending to legal persons in the Krasnoyarsk Territory, \% [The Bank of Russia]

\begin{tabular}{|l|c|c|c|c|c|c|c|c|}
\hline \multicolumn{1}{|c|}{ Region } & $\mathbf{2 0 0 8}$ & $\mathbf{2 0 0 9}$ & $\mathbf{2 0 1 0}$ & $\mathbf{2 0 1 1}$ & $\mathbf{2 0 1 2}$ & $\mathbf{2 0 1 3}$ & $\mathbf{2 0 1 4}$ & $\mathbf{2 0 1 5}$ \\
\hline Siberian Federal District & $\mathbf{4 \%}$ & $\mathbf{6 \%}$ & $\mathbf{6 \%}$ & $\mathbf{5 \%}$ & $\mathbf{5 \%}$ & $\mathbf{4 \%}$ & $\mathbf{7 \%}$ & $\mathbf{9 \%}$ \\
\hline The Republic Altai & $5 \%$ & $7 \%$ & $14 \%$ & $8 \%$ & $11 \%$ & $9 \%$ & $13 \%$ & $23 \%$ \\
\hline The Republic of Buryat & $3 \%$ & $8 \%$ & $12 \%$ & $6 \%$ & $3 \%$ & $3 \%$ & $5 \%$ & $12 \%$ \\
\hline The Republic of Tuva & $4 \%$ & $3 \%$ & $3 \%$ & $3 \%$ & $2 \%$ & $1 \%$ & $1 \%$ & $5 \%$ \\
\hline The Republic of Khakassia & $10 \%$ & $9 \%$ & $3 \%$ & $3 \%$ & $3 \%$ & $2 \%$ & $3 \%$ & $7 \%$ \\
\hline The Altai Territory & $4 \%$ & $5 \%$ & $8 \%$ & $10 \%$ & $20 \%$ & $10 \%$ & $10 \%$ & $15 \%$ \\
\hline The Zabaikalye Territory & $4 \%$ & $12 \%$ & $8 \%$ & $3 \%$ & $2 \%$ & $2 \%$ & $2 \%$ & $1 \%$ \\
\hline The Krasnoyarsk Territory & $5 \%$ & $6 \%$ & $7 \%$ & $3 \%$ & $1 \%$ & $3 \%$ & $3 \%$ & $2 \%$ \\
\hline The Irkutsk Region & $4 \%$ & $6 \%$ & $4 \%$ & $5 \%$ & $4 \%$ & $6 \%$ & $6 \%$ & $5 \%$ \\
\hline The Kemerovo Region & $1 \%$ & $5 \%$ & $4 \%$ & $3 \%$ & $2 \%$ & $2 \%$ & $4 \%$ & $12 \%$ \\
\hline The Novosibirsk Region & $3 \%$ & $5 \%$ & $5 \%$ & $4 \%$ & $4 \%$ & $5 \%$ & $7 \%$ & $9 \%$ \\
\hline The Omsk Region & $9 \%$ & $13 \%$ & $10 \%$ & $7 \%$ & $5 \%$ & $5 \%$ & $31 \%$ & $32 \%$ \\
\hline The Tomsk Region & $7 \%$ & $9 \%$ & $10 \%$ & $5 \%$ & $5 \%$ & $6 \%$ & $3 \%$ & $4 \%$ \\
\hline Russia & $\mathbf{3 \%}$ & $\mathbf{6 \%}$ & $\mathbf{5 \%}$ & $\mathbf{5 \%}$ & $\mathbf{5 \%}$ & $\mathbf{4 \%}$ & $\mathbf{5 \%}$ & $\mathbf{7 \%}$ \\
\hline
\end{tabular}

Table 3.3. Share of the past-due indebtedness in the total amount of lending to physical persons in the Krasnoyarsk Territory, \% [The Bank of Russia]

\begin{tabular}{|l|c|c|c|c|c|c|c|c|}
\hline \multicolumn{1}{|c|}{ Region } & $\mathbf{2 0 0 8}$ & $\mathbf{2 0 0 9}$ & $\mathbf{2 0 1 0}$ & $\mathbf{2 0 1 1}$ & $\mathbf{2 0 1 2}$ & $\mathbf{2 0 1 3}$ & $\mathbf{2 0 1 4}$ & $\mathbf{2 0 1 5}$ \\
\hline Siberian Federal District & $\mathbf{5 \%}$ & $\mathbf{7 \%}$ & $\mathbf{7 \%}$ & $\mathbf{5 \%}$ & $\mathbf{4 \%}$ & $\mathbf{5 \%}$ & $\mathbf{7 \%}$ & $\mathbf{9 \%}$ \\
\hline The Republic Altai & $3 \%$ & $5 \%$ & $5 \%$ & $5 \%$ & $4 \%$ & $5 \%$ & $6 \%$ & $9 \%$ \\
\hline The Republic of Buryat & $5 \%$ & $7 \%$ & $6 \%$ & $5 \%$ & $3 \%$ & $5 \%$ & $7 \%$ & $12 \%$ \\
\hline The Republic of Tuva & $5 \%$ & $5 \%$ & $5 \%$ & $4 \%$ & $4 \%$ & $6 \%$ & $8 \%$ & $9 \%$ \\
\hline The Republic of Khakassia & $4 \%$ & $6 \%$ & $6 \%$ & $4 \%$ & $3 \%$ & $4 \%$ & $6 \%$ & $8 \%$ \\
\hline The Altai Territory & $5 \%$ & $8 \%$ & $8 \%$ & $6 \%$ & $4 \%$ & $5 \%$ & $7 \%$ & $10 \%$ \\
\hline The Zabaikalye Territory & $3 \%$ & $5 \%$ & $4 \%$ & $3 \%$ & $3 \%$ & $3 \%$ & $5 \%$ & $7 \%$ \\
\hline The Krasnoyarsk Territory & $4 \%$ & $5 \%$ & $6 \%$ & $4 \%$ & $4 \%$ & $4 \%$ & $6 \%$ & $9 \%$ \\
\hline The Irkutsk Region & $5 \%$ & $6 \%$ & $6 \%$ & $4 \%$ & $4 \%$ & $4 \%$ & $6 \%$ & $9 \%$ \\
\hline The Kemerovo Region & $6 \%$ & $9 \%$ & $10 \%$ & $7 \%$ & $5 \%$ & $5 \%$ & $8 \%$ & $12 \%$ \\
\hline The Novosibirsk Region & $5 \%$ & $8 \%$ & $8 \%$ & $6 \%$ & $4 \%$ & $5 \%$ & $7 \%$ & $10 \%$ \\
\hline The Omsk Region & $6 \%$ & $9 \%$ & $10 \%$ & $7 \%$ & $5 \%$ & $6 \%$ & $7 \%$ & $10 \%$ \\
\hline The Tomsk Region & $3 \%$ & $5 \%$ & $5 \%$ & $4 \%$ & $3 \%$ & $4 \%$ & $5 \%$ & $7 \%$ \\
\hline Russia & $\mathbf{5 \%}$ & $\mathbf{7 \%}$ & $\mathbf{7 \%}$ & $\mathbf{5 \%}$ & $\mathbf{4 \%}$ & $\mathbf{4 \%}$ & $\mathbf{6 \%}$ & $\mathbf{8 \%}$ \\
\hline
\end{tabular}

The index of banking services availability allows comparing the banking development in this region with the all-Russian one: if one of any above mentioned indexes (И1, И2, ИЗ) appears to be less than 1 , so in the terms of this indicator the banking system remains short of the average national one and vice versa.

General development of the banking services in the Krasnoyarsk Territory is lower than the average one for Russia, since the territorial cumulated index is 0,86 . Such result 
Table 4. Sufficiency with the banking services in the Russian regions [The Bank of Russia]

\begin{tabular}{|l|c|c|c|c|c|c|c|c|}
\hline & \multicolumn{4}{|c|}{ The Krasnoyarsk Territory } & \multicolumn{4}{c|}{ The Novosibirsk Region } \\
\hline & И1 & И2 & И3 & CИ & И1 & И2 & И3 & СИ \\
\hline 01.01 .2016 & 1,04 & 0,96 & 0,63 & $\mathbf{0 , 8 6}$ & 0,98 & 0,82 & 1,07 & $\mathbf{0 , 9 5}$ \\
\hline 01.01 .2015 & 1,1 & 0,86 & 0,63 & $\mathbf{0 , 8 4}$ & 0,97 & 0,91 & 1,01 & $\mathbf{0 , 9 6}$ \\
\hline 01.01 .2014 & 1,13 & 0,76 & 0,66 & $\mathbf{0 , 8 3}$ & 0,98 & 1,09 & 0,95 & $\mathbf{1 , 0 0}$ \\
\hline 01.01 .2013 & 1,15 & 0,8 & 0,63 & $\mathbf{0 , 8 4}$ & 1,02 & 1,14 & 0,91 & $\mathbf{1 , 0 2}$ \\
\hline
\end{tabular}

И1 - institution saturation; И2 - finance saturation; ИЗ - thrift industry development index; СИ - cumulative index.

Table 5. Credit institutions' licenses termination in the Krasnoyarsk Territory, in units [The Bank of Russia]

\begin{tabular}{|c|c|c|c|c|c|c|c|c|c|c|c|}
\hline 1992 & 1993 & 1994 & 1998 & 1999 & 2000 & 2002 & 2004 & 2007 & 2010 & 2013 & 2016 \\
\hline 1 & 2 & 1 & 2 & 8 & 6 & 2 & 1 & 2 & 1 & 1 & 1 \\
\hline
\end{tabular}

is determined by the low level of thrift industry development: the population is less willing to keep their temporary available money in the credit institutions than on the average in Russia. To compare, in the neighbor Novosibirsk Region this indicator is above 1 .

At the present time, the banking services in the given territory are represented by 21 branches of extra-regional banks (such as Sberbank, Gazprombank, Alfa Bank and etc.), one branch of the local bank and four credit institutions registered in the Territory. They include: JSCB "Yenisei” (PJSC), CB “Kazanskiy", LLC; JSICB "Eniseisk United Bank"; NCO "Krasnoyarsk Territorial Processing Center" LLC. In 2016 the Territory has lost one of such banks: the consolidation procedure between "Kedr" and "BIN-Bank" banks has been completed and "Kedr" license has been terminated.

Over the recent years the number of regional banks has been consistently declining. Maximum losses were caused in 1999 when during the default on the obligations in Russia (State Treasury Bills and Federal Loan Bonds) the Bank of Russia supported only a number of selected federal banks. After that, for a variety of reasons, within 16 years 14 regional credit institutions which had made the banking services market vacant for the branches of federal and extra-regional banks were closed.

Not only regional banks have lost their positions in the territory, but also the department of the Bank of Russia in the Krasnoyarsk Territory has changed the status of Head Department into a Branch handing over a number of functions to the Siberian Head Department of the Bank of Russia in Novosibirsk. Even the leading federal banks eliminate their managing department from this region: in 2015 Sberbank closed the territorial department (East-Siberian Bank of Sberbank of Russia) and left the Head Branch in the Krasnoyarsk Territory. The close of department was accompanied by the staff reductions and functionality transferring to Moscow and Novosibirsk.

The analysis of banking sector in the territorial economy has demonstrated the loss of self-dependency in financial decisions-taking. Moreover, the high-calibre staff turns out to be non-demanded in this region within the absence of financial markets and credit institutions with developed functionality.

Summing up, let's note that the territorial economy is formed by highly-profitable enterprises, although their financial flows circulate outside the territory. The center of 
financial decision-taking has passed into the capital region which attracts the best members of the human capital.

\section{Conclusion}

The described investigation of the financial environment for the human capital development in the Krasnoyarsk Territory has outlined numerous negative trends. Firstly, the decreasing purchase power of the population and increasing share of statutory payments for the households reduce the number of investment sources for the human capital self-development. Secondly, the reduction of finance self-dependency of the regional budget, industrial and banking sector enterprises set the conditions for re-flowing human capital from the territory into other regions with a higher business activity, mainly, into the capital ones.

A possible shift of the regional economy to an innovation way of development is directly linked to the human capital efficiency the formation of which should be supported by favorable financial conditions - motivation and financial resources for the human capital self-development as well as creation of opportunities for the skills application within the given territory.

\footnotetext{
"Private households are a group of individuals living in a residential building, apartment, room or in a part of this residential building or apartment, who collectively provide themselves with the basic necessities of life and fully or partially join their incomes; or a person living in a residential building, apartment, room or in their parts, who independently sustain themselves with the basic necessities of life..." (The Order of the Federal State Statistics Service № 452 "Concerning Approval of Methodological Provisions on Sampling Population Survey on Employment (workforce survey)" dated on December 21, 2010.

2 In 2013 the US dollar's average exchange rate was 38,61 rubles for 1 dollar.

3 Calculated in rubles at the average USA dollar exchange rate in 2013

4 Calculated according to the RF consolidated budget data in 2014

5 Calculated according to the consolidated budget data of the USA in 2015 including national educational programs

6 Calculated according to the RF consolidated budget data in 2014

Calculated according to the consolidated budget data of the USA in 2013

8 Calculated according to the budget data of Krasnoyarsk Territorial Compulsory Medical Insurance Fund in 2015

9 Calculated according to the data available at https://www.cdc.gov/nchs/data/hus/2015/093.pdf

10 According to the Maastricht criteria, for the country this indicator shall not exceed 3\%

11 The Guidebook to Territorial Budget Implementation Report, 2015.

12 Including the non-budgetary fund incomes

13 Including the non-budgetary fund incomes

14 И1 - institution saturation: the number of branches per capita in the given region is divided by the similar indicator for Russia; И2 - finance saturation: the amount of lending to GRP and divided by the similar indicator for Russia; И3 - thrift industry development index: the amount of deposits per capita to cash incomes per capita and divided by the similar indicator for Russia; СИ - cumulative index: the geometric average for И1, И2, ИЗ.
}

\section{References}

Atlas New America. Available at: www.atlas.newamerica.org (accessed July 9, 2016).

Becker G.S. (1962). Investment in Human Capital: A Theoretical Analysis, In Journal of Political Economy, 70 (5), 9-49.

Digilina O.B. (2003). Chelovecheskii capital v sisteme trudovykh otnoshenii. [Human Capital in a System of Labor Relations]. Marketing, 2003.

EMISS Gosudarstvennaia statistika [State Statistics]. Available at: https://fedstat.ru/ (accessed July 13, 2016).

Federal'naia nalogovaia sluzhba [The Federal Tax Service]. Available at: https://www.nalog.ru/ (accessed 15 July 2016).

Federal'naia sluzhba gosudarstvennoi statistiki [The Federal State Statistics Service]. Available at: www.gks.ru (accessed July 13, 2016).

Finam - investment company. Available at: https://www.finam.ru/ (accessed July 10, 2016). 
List F. (2005). Natsionalnaia sistema politicheskoi ekonomii. [National System of Political Economy]. Moscow, Europe.

Ministerstvo finansov Krasnoiarskogo kraia [The Ministry of Finance of the Krasnoyarsk Territory]. Available at: http://minfin.krskstate.ru/ (accessed July 15, 2016).

Schultz Th. W. (1981). Investing in people, In The Economics of pPopulation Quality. Berkeley: University of California Press.

Territirialnii organ Federalnoi sluzhby gosudarstvennoi statistiki po Krasnoiarskomu kraiu [The Krasnoyarsk Territorial State Statistic Service]. Available at: http://krasstat.gks.ru/ (accessed July 15, 2016).

Tsentralnii bank Rossiiskoi Federatsii [The Bank of Russia]. Available at: www.cbr.ru (accessed July 11, 2016).

U.S. Bureau of Labor Statistics. Available at: www.biz.gov/ (accessed July 8, 2016).

\title{
Анализ финансовых условий \\ развития человеческого капитала региона \\ на примере Красноярского края
}

Т.С. Зимнякова

Сибирский федеральный университет

Россия, 660041, Красноярск, пр. Свободный, 79

\begin{abstract}
Человеческий капитал является важнейшим фактором инновационного развития экономи$\kappa и$. В этой связи особую актуальность приобретает изучение условий, способствуюших его эффективному формированию. В настоящей статье исследуются финансовые условия развития человеческого капитала региона на примере Красноярского края. В статье анализируется состояние финансов региональных экономических агентов - домашних хозяйств, предприятий, кредитных организачий, а также государственные финансы региона. Результаты анализа выявили ухудшение финансовых условий развития человеческого капитала. Снижение покупательной способности населения, конщентрация налоговых поступлений и финансовых потоков предприятий в столичном регионе - все это является негативными финансовыми стимулами для развития человеческого капитала на территории края. Итоги исследования могут служить основой для разработки политики по интенсификации инновационного развития региона.

Ключевые слова: человеческий капитал, инновационное развитие, финансы домамних хозяйств, региональный бюджет, негосударственные финансы.

Статья написана при финансовой поддержке краевого государственного автономного учреждения "Красноярский краевой фонд поддержки научной и научно-технической деятельности», проект "Методологические подходы к оценке и разработке структурной политики человеческого капитала для обеспечения стратегии устойчивого развития Красноярского края с точки зрения диверсификации и технологической модернизации экономики» 6 рамках сочиального и человеческого исследований, разработок и инновачий, направленных на улучшение качества жизни населения Красноярского края в 2016 году.
\end{abstract}

Научная специальность: 08.00.00 - экономические науки, 24.00.00 - культурология. 